Volume 1, Number 1, 2015

\title{
Heat Exchange between Thermometer Well and Pipe Wall in Natural Gas Metering Systems
}

\author{
Roman Fedoryshyn ${ }^{*}$, Fedir Matiko \\ Lviv Polytechnic National University, S. Bandery Str., 12, Lviv, 79013, Ukraine \\ Received: April 02, 2015. Revised: May 13, 2015. Accepted: May 13, 2015.
}

(C) 2015 The Authors. Published by Lviv Polytechnic National University.

\begin{abstract}
This paper deals with the accuracy of gas flow temperature measurement in natural gas metering systems. The effect of heat exchange between thermometer well and the pipe wall on the accuracy of gas flow temperature measurement is investigated. A mathematical model is proposed to calculate the additional systematic error of gas flow temperature measurement caused by heat exchange between thermometer well and the pipe wall. Calculation results were compared to the corresponding experimental values of this error. The maximum relative deviation of calculation results from experimental values does not exceed $6 \%$. The effect of gas flow temperature measurement error on the accuracy of gas flow rate and volume measurement is analyzed. Measures are proposed to minimize the additional systematic error of gas flow temperature measurement and to improve the accuracy of natural gas metering.
\end{abstract}

Keywords: gas flow; temperature; measurement; heat exchange; systematic error.

\section{Introduction}

Natural gas is one of strategically important energy carriers. The measurement of the flow rate and the volume of natural gas should be carried out at each step of its supply and the accuracy of such measurement should be improved.

The absence of natural gas metering means the absence of control of its use, which always leads to inefficient use of gas and thus to its losses. When there is no metering, it is impossible to detect the real losses of natural gas (especially unpredicted losses) and to calculate and analyze the balances (and unbalances) in gas transportation and distribution systems. The absence of metering makes it impossible to establish normal economic relations between the supplier and the consumer of natural gas. When metering is carried out inaccurately, all the problems mentioned above also take place within the limits of the measurement error (measurement uncertainty) [1]. That is why it is very important to know all the systematic errors in the natural gas metering system in order to be able to define them and take measures to eliminate them.

Natural gas metering is often carried out in conditions when gas flow temperature is different from the temperature of ambient air (e.g. in winter time when cold gas from outside enters a warm building of a boiler house; in summer time when warm gas from outside enters a cool building of a boiler house and other). In such conditions the additional systematic error of gas flow temperature measurement and errors of flow rate and volume measurement can take place due to the effect of heat exchange processes in the metering system [2]. By taking into account and eliminating these additional errors of measurement we can significantly improve the accuracy of natural gas metering.

The goal of this work is to define the effect of heat exchange between thermometer well and the pipe wall in gas metering systems on the accuracy of flow temperature measurement, to carry out the calculation of additional error of gas flow temperature measurement caused by heat exchange between thermometer well and the pipe wall, to compare

\footnotetext{
* Corresponding author. Email address: romanfedoryshyn@yahoo.com
} 
the calculation results with experimental data as well as to propose measures in order to eliminate this error of flow temperature measurement and the subsequent error of gas flow rate and volume measurement.

\section{Mathematical model}

If the gas flow temperature is different from that of the ambient air, the temperature of the immersed tip of thermometer well is different from that of the pipe wall and as a result heat exchange between them takes place in the following two ways: heat conduction and heat radiation (see Fig. 1). At gas temperatures typical

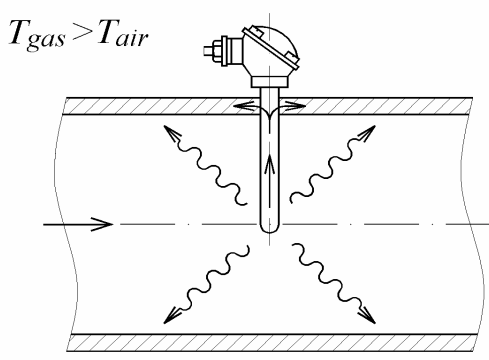

Fig. 1. Heat exchange between thermometer well and the pipe wall for gas transportation and gas distribution systems, heat exchange by heat conduction is of a higher intensity than heat exchange by heat radiation.

The heat exchange between thermometer well and the pipe wall leads to additional error of gas flow temperature measurement, denoted by us as $\Delta T_{T}$. The $\Delta T_{T}$ error represents the difference between actual gas temperature in the place of thermometer mounting and the gas temperature measured by thermometer (without taking into account the metrological characteristics of thermometer sensor). On the basis of the previous theoretical analysis we propose the value of $\Delta T_{T}$ error to be calculated with the application of the following formulae [2]:

$$
\begin{gathered}
\Delta T_{T}=\Delta T_{T C}+\Delta T_{T R} \\
\Delta T_{T C}=-\frac{T_{R T}-T_{i n}}{\operatorname{ch}\left(b \cdot L_{T I}\right)} \cdot \frac{\operatorname{sh}\left(b \cdot L_{T S}\right)}{b \cdot L_{T S}} \\
\Delta T_{T R}=-\frac{c_{0} \cdot \varepsilon_{T}}{\alpha_{T}} \cdot\left(\left(\frac{T_{R T}}{100}\right)^{4}-\left(\frac{T_{i n}}{100}\right)^{4}\right),
\end{gathered}
$$

where $\Delta T_{T C}$ and $\Delta T_{T R}$ are errors caused by heat exchange between thermometer well and the pipe wall by heat conduction and by heat radiation respectively; $T_{R T}$ is the temperature registered by thermometer; $T_{i n}$ is the temperature of pipe internal surface (can be calculated according to [3]); $L_{T I}$ is the depth of thermometer immersion into the pipe; $L_{T S}$ is the length of thermometer sensing element; $b$ is the coefficient that depends on design characteristics of thermometer and heat transfer coefficient from gas flow to thermometer well; $c_{0}=5.67 \mathrm{Wt} /\left(\mathrm{m}^{2} \cdot \mathrm{K}^{4}\right)$ is the black body heat radiation coefficient; $\varepsilon_{T}$ is thermometer well blackness rate; $\alpha_{T}$ is the convective heat transfer coefficient from gas flow to thermometer well (can be calculated according to [3]).

The $\Delta T_{T}$ error can be both positive and negative and its value depends significantly on the temperature difference between gas flow and the ambient air, the flow rate and pressure of gas, wall thickness of thermometer well and the depth of thermometer immersion into the pipe. The calculation of the $\Delta T_{T}$ error using the formulae (1)-(3) and comparison of the calculated values with experimental results are presented in the following parts of this paper.

\section{Experimental investigation}

Experimental investigation of the effect of heat exchange between thermometer well and the pipe wall on the accuracy of gas flow temperature measurement was carried out by TransCanada PipeLines Limited (TCPL) highpressure Gas Dynamic Test Facility (GDTF) near Didsbury, Alberta, Canada [4]. There were four temperature transducers installed at the same axial location and evenly spaced at four radial positions. An environmental temperature control box was installed on the pipe to control the temperature of ambient air around the pipe. The tests were conducted on the NPS8 Schedule 40 pipe. The following temperature transducers were installed into wells:

- TR-0.40D - reference gas temperature measurement, WIKA Instruments Ltd. [5];

- TW-0.33D - standard thermometer well PW15-3, WIKA Instruments Ltd.;

- TW-0.21D - standard thermometer well PW15-2, WIKA Instruments Ltd.;

- TS-0.22D - special design well, PGI International's ThermoSync L2. 
The average value of natural gas temperature was $15^{\circ} \mathrm{C}$ and the gas pressure was equal to $6100 \mathrm{kPa}$. The temperature of the air in the environment control box was set successively to the following values: $20{ }^{\circ} \mathrm{C} ; 35^{\circ} \mathrm{C}$; $50{ }^{\circ} \mathrm{C}$. Gas flow velocity was set successively to the following values (during each controlled value of air temperature): $3.3 \mathrm{~m} / \mathrm{sec} ; 2.2 \mathrm{~m} / \mathrm{sec} ; 1.1 \mathrm{~m} / \mathrm{sec} ; 0.5 \mathrm{~m} / \mathrm{sec}$.

In our analysis we take into consideration experimental results for the air temperatures of $35{ }^{\circ} \mathrm{C}$ and $50{ }^{\circ} \mathrm{C}$ and for gas flow velocities of $3.3 \mathrm{~m} / \mathrm{sec} ; 2.2 \mathrm{~m} / \mathrm{sec}$ and $1.1 \mathrm{~m} / \mathrm{sec}$ when the effect of heat exchange between thermometer well and the pipe wall on the accuracy of gas flow temperature measurement was significant. The analysis of $\Delta T_{T}$ error is carried out for the following thermometer wells: TW-0.33D and TW-0.21D.

The experimental values of $\Delta T_{T}$ error [4] are given in Tables 1,2 .

Table 1. Experimental values of $\Delta \mathrm{T}_{\mathrm{T}}$ error for TW-0.33D [4]

\begin{tabular}{|c|c|c|c|c|}
\hline \multicolumn{2}{|c|}{} & \multicolumn{3}{|c|}{ Velocity of gas flow, m/sec } \\
\cline { 2 - 5 } \multicolumn{2}{|c|}{} & 1.1 & 2.2 & 3.3 \\
\hline \hline \multirow{2}{*}{$\begin{array}{c}\text { Temperature of air, } \\
{ }^{\circ} \mathrm{C}\end{array}$} & 35 & 0.37 & 0.25 & 0.2 \\
\cline { 2 - 5 } & 50 & $\begin{array}{c}0.57 \ldots \\
0.6\end{array}$ & $\begin{array}{c}0.45 \ldots \\
0.55\end{array}$ & $\begin{array}{c}0.39 \ldots \\
0.5\end{array}$ \\
\hline
\end{tabular}

Table 2. Experimental values of $\Delta \mathrm{T}_{\mathrm{T}}$ error for TW-0.21D [4]

\begin{tabular}{|c|c|c|c|c|}
\hline \multirow{2}{*}{} & \multicolumn{3}{|c|}{ Velocity of gas flow, $\mathrm{m} / \mathrm{sec}$} \\
\cline { 3 - 5 } \multicolumn{2}{|c|}{} & 1.1 & 2.2 & 3.3 \\
\hline \hline \multirow{3}{*}{$\begin{array}{c}\text { Temperature of air, } \\
{ }^{\circ} \mathrm{C}\end{array}$} & 35 & 0.48 & 0.3 & 0.21 \\
\cline { 2 - 5 } & \multirow{2}{*}{50} & $0.79 \ldots$ & $0.56 \ldots$ & $0.43 \ldots$ \\
& & 0.87 & 0.67 & 0.54 \\
\hline
\end{tabular}

Formulae (1)-(3) were applied to calculate the $\Delta T_{T}$ error for the conditions of the experimental test facility [4]. And the calculated values of $\Delta T_{T}$ error were compared to the corresponding experimental values of this error (see Table 3 and Fig. 2, 3). The smaller experimental values of $\Delta T_{T}$ error were taken for comparison with the calculated values of this error for reliability considerations. The following denotations are made in Table 3: $v_{g}$ is the velocity of gas flow, $T_{a}$ is the temperature of air in the environment control box; $\Delta$ is the absolute deviation of calculated values of $\Delta T_{T}$ error from the corresponding experimental values; $\delta$ is the relative deviation of calculated values of $\Delta T_{T}$ error from the corresponding experimental values.

As we can see from Fig. 2, 3 the $\Delta T_{T}$ error decreases with the increase of gas flow velocity and the value of this error is bigger at higher temperature of air in the environment control box. The $\Delta T_{T}$ error is bigger for the thermometer well TW-0.21D than for the TW-0.33D because the depth of immersion of the first one into the pipe is smaller.

Table 3. Comparison of calculated values of $\Delta \mathrm{T}_{\mathrm{T}}$ error with the experimental values

\begin{tabular}{|c|c|c|c|c|c|c|c|c|}
\hline \multirow{2}{*}{$v_{g} / T_{a}$} & \multicolumn{9}{|c|}{$\Delta T_{T}{ }^{\circ} \mathrm{C}$} \\
\cline { 2 - 9 } & Calc. & Experim. & $\Delta,{ }^{\circ} \mathrm{C}$ & $\delta, \%$ & Calc. & Experim. & $\Delta,{ }^{\circ} \mathrm{C}$ & $\delta, \%$ \\
\hline \hline $1.1 / 35$ & 0.361 & 0.37 & -0.009 & -2.3 & 0.473 & 0.48 & -0.007 & -1.5 \\
\hline $2.2 / 35$ & 0.239 & 0.25 & -0.011 & -4.2 & 0.288 & 0.30 & -0.012 & -4.0 \\
\hline $3.3 / 35$ & 0.188 & 0.20 & -0.012 & -5.9 & 0.198 & 0.21 & -0.012 & -5.7 \\
\hline $1.1 / 50$ & 0.563 & 0.57 & -0.007 & -1.2 & 0.783 & 0.79 & -0.007 & -0.9 \\
\hline $2.2 / 50$ & 0.438 & 0.45 & -0.012 & -2.6 & 0.549 & 0.56 & -0.011 & -2.0 \\
\hline $3.3 / 50$ & 0.372 & 0.39 & -0.018 & -4.6 & 0.416 & 0.43 & -0.014 & -3.2 \\
\hline
\end{tabular}




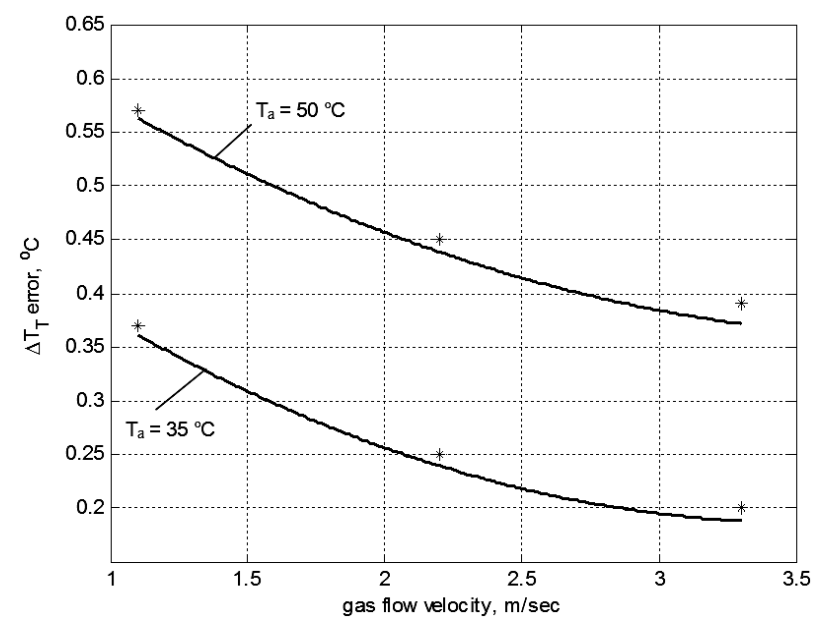

Fig. 2. $\Delta T_{T}$ error versus gas flow velocity for TW-0.33D at the temperature of air in the environment control box equal to $35^{\circ} \mathrm{C}$ and $50^{\circ} \mathrm{C}:{ }^{*}$ - experimental values; - calculated values

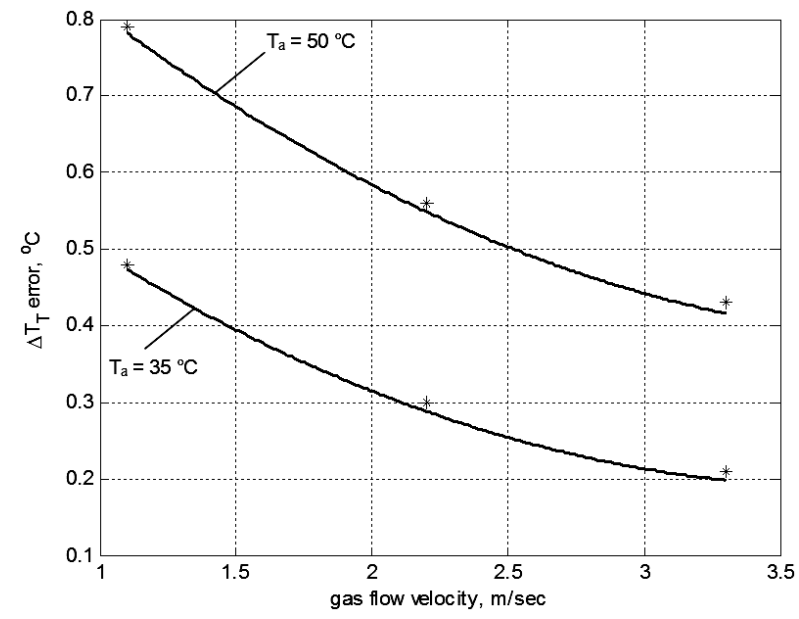

Fig. 3. $\Delta T_{T}$ error versus gas flow velocity for TW-0.21D at the temperature of air in the environment control box equal to $35{ }^{\circ} \mathrm{C}$ and $50{ }^{\circ} \mathrm{C}$ : * - experimental values; - calculated values

It can be seen from the comparison results that the calculated values of the $\Delta T_{T}$ error are close to corresponding experimental values. The maximum relative deviation of calculated values from the experimental values is $-5.9 \%$ for TW-0.33D and $-5.7 \%$ for TW-0.21D. Thus we conclude that the proposed formulae (1)-(3) can be applied to calculate the $\Delta T_{T}$ error and to define the effect of the heat exchange between thermometer well and the pipe wall on the accuracy of gas flow temperature measurement.

\section{The effect of flow temperature measurement error on the accuracy of gas volume measurement}

The systematic error of flow temperature measurement in a gas metering system leads to systematic errors of gas flow rate and volume measurement. Based on the investigation carried out by us earlier using the formulae and coefficients from [6], [7], the relation between the error of flow temperature measurement and the error of gas volume measurement in a low pressure gas metering system can be defined as:

$$
\delta_{V} \approx-0.34 \cdot \Delta_{T},
$$

where $\Delta_{T}$ is the absolute error of gas temperature measurement $\left({ }^{\circ} \mathrm{C}\right), \delta_{V}$ is the relative methodical error of gas volume measurement (\%).

The formula (4) was obtained on the basis of a technique for converting the volume of gas from one base temperature to another. According to formula (4), the absolute error of gas flow temperature measurement equal to $+1{ }^{\circ} \mathrm{C}$ leads to a relative methodical error of gas volume measurement equal to approximately $-0.34 \%$ for a low pressure gas metering system.

Let us consider a branch of a gas distributing network where there are 10 consumers (boiler houses) with a nominal gas flow rate of $200 \mathrm{~m}^{3} / \mathrm{h}$ for each consumer (converted to the base conditions: $20^{\circ} \mathrm{C}, 101.325 \mathrm{kPa}$ ). If the gas metering systems are installed inside the buildings with heating, then in winter time heat exchange processes may take place in the metering systems and an additional error of gas flow temperature measurement may occur. Let us assume that there is an additional error of gas flow temperature measurement $\Delta T_{T}=+0.5^{\circ} \mathrm{C}$ in each system. Then there will be an additional systematic error of gas flow rate measurement equal to $-0.17 \%$ in each system, which is equal to $-0.34 \mathrm{~m}^{3} / \mathrm{h}$ or $-8.16 \mathrm{~m}^{3} /$ day or $-244.8 \mathrm{~m}^{3} /$ month. The total gas unbalance in this branch of a gas distributing network will be equal to $-2448 \mathrm{~m}^{3} / \mathrm{month}$, which is equivalent to $-1187 \mathrm{USD} / \mathrm{month}$ (at $485 \mathrm{USD} / 1000 \mathrm{~m}^{3}$ the price of natural gas for industrial consumers in Ukraine, March 2015). The unbalance may be even bigger if there are other systematic errors in gas metering systems [8]. 
The negative unbalance in a gas distributing system leads to an increase in gas price. That is why it is very important to eliminate additional systematic errors of gas flow rate and volume measurement that cause unbalances in gas distributing systems.

\section{Elimination of the $\Delta T_{T}$ error}

The following measures are proposed to eliminate the $\Delta T_{T}$ error: the installation of heat insulation on the pipe of the flow measurement system; the installation of thermometer directly into the gas flow using heat insulating gaskets; the application of a specially designed well. By installing heat insulation on the pipe of the flow measurement system, the pipe wall temperature will be close to the gas flow temperature and the heat exchange between thermometer well and the pipe wall will be negligible. It is important to design heat insulation correctly so that the thickness of the heat insulation is big enough to eliminate the $\Delta T_{T}$ error.

Thermometer installation directly into the gas flow using heat insulating gaskets will reduce the thermal contact of thermometer with the pipe significantly. And in this way the $\Delta T_{T}$ error will be reduced significantly. However, this type of thermometer installation can be done only for gas metering systems with the maximum pressure of $1 \mathrm{MPa}$.

Another way to reduce the $\Delta T_{T}$ error significantly is to install the thermometer into a specially designed well that has fins. Circular fins at the tip of the well improve the surface area contact with the gas flow and the temperature of the immersed tip of thermometer can be considered equal to the gas flow temperature. However, such a well makes distortions in the flow structure and it is recommended to install such a well downstream of the flow meter.

\section{Conclusion}

Temperature conditions in a gas metering system may lead to heat exchange processes that cause additional errors of gas flow temperature measurement. One of the errors is the error caused by the heat exchange between thermometer well and the pipe wall, denoted by us as $\Delta T_{T}$. The $\Delta T_{T}$ error can be calculated using the proposed formulae (1)-(3). Based on the comparison of the calculated values of the $\Delta T_{T}$ error with experimental values of this error it was defined that the formulae (1)-(3) provide results close to the experimental values. The maximum relative deviation of calculation results from experimental values does not exceed $6 \%$. The accuracy of the proposed formulae (1)-(3) is high enough to apply them in practice for defining the effect of heat exchange between thermometer well and the pipe wall on the accuracy of gas flow temperature measurement.

A positive error of gas flow temperature measurement leads to a negative error of gas flow rate and volume measurement. The values of the errors are more significant at a big difference between gas flow temperature and ambient air temperature, at small flow rates and in systems with small pipe diameters.

To eliminate the $\Delta T_{T}$ error it is proposed to install heat insulation on the pipe of the flow measurement system, to install the thermometer directly into the gas flow using heat insulating gaskets or to apply a special designed well with fins.

Definition and elimination of the additional error of gas flow temperature measurement caused by the heat exchange between thermometer well and the pipe wall is an important step towards the improvement of accuracy of natural gas metering.

\section{Acknowledgements}

The research was supported by The Ministry of Education and Science of Ukraine and by The University of Iowa.

\section{References}

[1] Pistun Y. Normalization of pressure differential flowmeters / Y. Pistun, L. Lesovoi // Publishing House of Institute of Energy Audit and Energy Carrier Accounting. - Lviv, 2006. - 576 p. (in Ukrainian).

[2] Fedoryshyn R. Influence of heat exchange processes on the accuracy of natural gas volume measurement / R. Fedoryshyn, F. Matiko, Ye. Pistun // Papers of The 15th VDE/ITG/GMA Conference "Sensors and Measuring Systems 2010". Nuremberg, Germany. - 2010. P. 597-601

[3] Labay V. Heat and mass exchange / V. Labay. - Lviv: Triada Plus Publishing House, 2004. - 260 p. (in Ukrainian). 
[4] R. McBrien. Effect of low flow and extreme ambient conditions on thermowell performance / R. McBrien, J. Geerligs // Proceedings of The 8th ISFFM. - Colorado Springs, CO, USA. - June 20-22, 2012. - P. 1-9.

[5] WIKA Instruments Ltd., Product Catalogue, $8^{\text {th }}$ ed., June 2007.

[6] ISO 13443:1996 Natural gas - Standard reference conditions.

[7] MVU 034/03-2008 Volume of Natural Gas at Standard Conditions. Typical technique of measurement by means of a gas meter and a corrector of the gas volume.

[8] Ficco G. Metrological performance of diaphragm gas meters in distribution networks. Flow Measurement and Instrumentation / G. Ficco, 2014. - P. 37, 65-72. http://dx.doi.org/10.1016/j.flowmeasinst.2014.03.005

\title{
Теплообмін між гільзою термоперетворювача та стінкою трубопроводу в системах обліку природного газу
}

\author{
Роман Федоришин, Федір Матіко \\ Національний університет “Львівська політехніка”, вул. С. Бандери, 12, м. Львів, 79013, Україна
}

\section{Анотація}

Досліджено точність вимірювання температури потоку природного газу в системах його обліку. Виконано дослідження впливу теплообміну між гільзою термоперетворювача та стінкою трубопроводу на точність вимірювання температури потоку газу. Запропоновано математичну модель для розрахунку додаткової систематичної похибки вимірювання температури потоку газу, зумовленої теплообміном між гільзою термоперетворювача та стінкою трубопроводу. Виконано порівняння результатів розрахунку цієї похибки 3 відповідними експериментальними значеннями. Максимальне відносне відхилення результатів розрахунку від експериментальних значень не перевищує $6 \%$. Проаналізовано вплив похибки вимірювання температури потоку газу на точність вимірювання витрати та кількості газу. Запропоновано заходи для мінімізації додаткової систематичної похибки вимірювання температури потоку газу та для підвищення точності обліку природного газу.

Ключові слова: потік газу; температура; вимірювання; теплообмін; систематична похибка. 